\title{
Guillain Barre Syndrome in Children : Case Report
}

\author{
Rino Puji Dwi Sukmawana, Sri Mardjiati Mei Wulan ${ }^{\mathrm{b}}$ \\ sukmawanrino@gmail.com

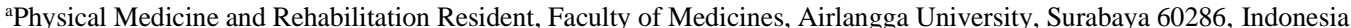 \\ bDepartment of Physical Medicine and Rehabilitation, Faculty of Medicines, Airlangga University, Surabaya 60286, Indonesia
}

\begin{abstract}
Background: The incidence of GBS at the age of <15 years is 1.5 cases per 100,000 population and peaks at the age of 7079 years, reaching 8.6 cases per 100,000 population. The peak of this disease at the age of 15-35 years and 50-75 years. Infants are said to have the lowest risk of developing GBS. Male have 1.5 times greater risk than female

Case: a 7 years old male children was presented with main complaint of weakness at extrimites on both side since March 27th, 2019. Patient felt weakness at lower extremities first and then followed by upper extremities two days later. patient cannot use his hand and leg at all. patient was unable to transfer from lying to sitting independently and unable to slide his buttocks. patient felt numbness on his both arms and leg. patient got dyspepsia one week before weakness. Based on physical and diagnostic examination patient diagnosed with Tetraparesis LMN type due to Guillan Barre Syndrome (GBS). Patient got rehabilitation program consist of NMES, ROM, active breathing, endurance, strengthening, transfer and mobilization exercise, and occupational therapy. Patient got improvement in muscle power of upper and lower extremities after five (5) month rehabilitation medicines. Barthel index improved from 25 to 95 and activity daily living independently.
\end{abstract}

Conclusion: NMES, ROM, active breathing, endurance, strengthening, transfer and mobilization exercise, and occupational therapy can improve muscle power of upper and lower extremities for GBS of male children in five month rehabilitation program.

Keywords: Guillain Barre Syndrome; children; physical exercise.

\section{Introduction}

Guillain Barre Syndrome (GBS) is a demyelinating neuropathy characterized by ascending weakness and reduced/loss of reflexes and can affect cranial nerves. GBS is the most important cause of acute flaccid paralysis (Andary, 2021). The incidence of GBS in the United States is 1.2-3 out of 100,000 population/year and increases with age.

The incidence of GBS at the age of $<15$ years is 1.5 cases per 100,000 population and peaks at the age of 70-79 years, reaching 8.6 cases per 100,000 population. The peak of this disease at the age of 15-35 years and 50-75 years. Infants are said to have the lowest risk of developing GBS. Men have 1.5 times greater risk than women (Van Doorn and Drenthen, 2014; Andary, 2021).

The cause of GBS itself is still unknown for certain, but there is an opinion that one of the triggers for GBS is a viral or bacterial infection such as Campylobacter Jejuni or Citomegalovirus (Craig, Richardson and Ayyangar, 2016). GBS begins with motor weakness and takes time to heal. Although GBS is said to be self-limiting disease, some patients experience sequelae. therefore, it is important for physical medicine and rehabilitation specialists to recognize the signs of GBS and determine the appropriate rehabilitation program for individuals affected by GBS.

\section{Case Report}

a 7 years old male children was presented with main complaint of weakness at extrimites on both side since March 27th, 2019. Patient felt weakness at lower extremities first and then followed by upper extremities two days later. patient cannot use his hand and leg at all. patient was unable to transfer from lying to sitting independently and unable to slide his buttocks. patient felt numbness on his both arms and leg. patient got dyspepsia one week before weakness.

History of present illness are felt weakness at both of arm, hand, leg, and foot. Weakness at both of legs since 5 days before hospitalized. Weakness more prominent until he cannot move his foot and cannot walk. Weakness of the arm and hand since two days before hospitalized, but he can move his upper extremities a little. He also felt difficulty in swallowing. Patient also experienced difficult of breath. After his breathing difficulties improved, he was hospitalized for 2 days. His condition when discharge (18 April 2019) was stable in respiration but still bed ridden and cannot use both of hand. Difficulty of swallowing was absence. Slurred speech and asymetrical face was denied, difficulty in urination and defecation was denied, history of cough, fever denied, he only felt dyspepsia one week before weakness. 
Prenatal history of Patient is a $2^{\text {nd }}$ child of 2 siblings, her mother was taken antenatal care routinely, aterm, normal delyy labor with $3000 \mathrm{gr}$ weight and $50 \mathrm{~cm}$ height. Complete immunization, no history of seizure and lung Tuberculosis.

On April 1 ${ }^{\text {st }}, 2019$ General examination shows that patient is bed ridden, Glasgow Coma Points: E4M5V6, BP: 110/60 mmHg, Pulse: 116 bpm, Respiration: 24x/min, T: 36, $6^{\circ} \mathrm{C}, \mathrm{SpO}_{2}$ : $98 \%$ room air, weight: $18 \mathrm{Kg}$, weight: $120 \mathrm{~cm}$, BMI: 16,67 $\mathrm{Kg} / \mathrm{m}^{2}$, Barthel index is 25 (severely dependent). Head and neck: not anaemic, no jaundice, and no cyanosis. Heart sound is nomal, no murmur and no gallop sound, lung sound is vesicular on both side, no ronchi, no wheezing, abdomen is soft, liver and spleen is unpalpable.

Musculosceletal status on the table 1, neurological and functional examination on the table 2

Table 1. Musculosceletal Status

\begin{tabular}{|c|c|c|c|}
\hline Part of Body & Movement & ROM & MMT \\
\hline \multirow[t]{4}{*}{ Neck } & Flexion & F & 1 \\
\hline & Extension & $\mathrm{F}$ & 1 \\
\hline & Lateral Bending & $\mathrm{F} / \mathrm{F}$ & $1 / 1$ \\
\hline & Rotation & $\mathrm{F} / \mathrm{F}$ & $1 / 1$ \\
\hline \multirow[t]{4}{*}{ Trunk } & Flexion & $\mathrm{F}$ & Impressed $<3$ \\
\hline & Extension & $\mathrm{F}$ & Impressed $<3$ \\
\hline & Lateral Bending & $\mathrm{F} / \mathrm{F}$ & Impressed $<3$ / Impressed $<3$ \\
\hline & Rotation & $\mathrm{F} / \mathrm{F}$ & Impressed $<3$ Impressed $<3$ \\
\hline \multirow[t]{6}{*}{ Shoulder } & Flexion & $\mathrm{F} / \mathrm{F}$ & $2 / 2$ \\
\hline & Extension & $\mathrm{F} / \mathrm{F}$ & $2 / 2$ \\
\hline & Abduction & $\mathrm{F} / \mathrm{F}$ & $2 / 2$ \\
\hline & Adduction & $\mathrm{F} / \mathrm{F}$ & $2 / 2$ \\
\hline & External Rotation & $\mathrm{F} / \mathrm{F}$ & $2 / 2$ \\
\hline & Internal Rotation & $\mathrm{F} / \mathrm{F}$ & $2 / 2$ \\
\hline \multirow[t]{4}{*}{ Elbow } & Flexion & $\mathrm{F} / \mathrm{F}$ & $2 / 2$ \\
\hline & Extension & $\mathrm{F} / \mathrm{F}$ & $2 / 2$ \\
\hline & Pronation & $\mathrm{F} / \mathrm{F}$ & $2 / 2$ \\
\hline & Supination & $\mathrm{F} / \mathrm{F}$ & $2 / 2$ \\
\hline \multirow{2}{*}{ Wrist } & Flexion & $\mathrm{F} / \mathrm{F}$ & $2 / 2$ \\
\hline & Extension & $\mathrm{F} / \mathrm{F}$ & $2 / 2$ \\
\hline \multirow[t]{6}{*}{ Thumb } & Flexion MCP & $\mathrm{F} / \mathrm{F}$ & $1 / 1$ \\
\hline & PIP & $\mathrm{F} / \mathrm{F}$ & $1 / 1$ \\
\hline & Extension & $\mathrm{F} / \mathrm{F}$ & $1 / 1$ \\
\hline & Abduction & $F / F$ & $1 / 1$ \\
\hline & Adduction & $\mathrm{F} / \mathrm{F}$ & $1 / 1$ \\
\hline & Opposition & $\mathrm{F} / \mathrm{F}$ & $1 / 1$ \\
\hline \multirow{6}{*}{ Fingers } & Flexion MCP & $\mathrm{F} / \mathrm{F}$ & $1 / 1$ \\
\hline & PIP & $\mathrm{F} / \mathrm{F}$ & $1 / 1$ \\
\hline & DIP & $\mathrm{F} / \mathrm{F}$ & $1 / 1$ \\
\hline & Extension & $\mathrm{F} / \mathrm{F}$ & $1 / 1$ \\
\hline & Abduction & $\mathrm{F} / \mathrm{F}$ & $1 / 1$ \\
\hline & Adduction & $\mathrm{F} / \mathrm{F}$ & $1 / 1$ \\
\hline \multirow[t]{6}{*}{ Hip } & Flexion & $\mathrm{F} / \mathrm{F}$ & $1 / 1$ \\
\hline & Extension & $\mathrm{F} / \mathrm{F}$ & $1 / 1$ \\
\hline & Abduction & $\mathrm{F} / \mathrm{F}$ & $1 / 1$ \\
\hline & Adduction & $\mathrm{F} / \mathrm{F}$ & $1 / 1$ \\
\hline & External Rotation & $F / F$ & $1 / 1$ \\
\hline & Internal Rotation & $\mathrm{F} / \mathrm{F}$ & $1 / 1$ \\
\hline \multirow[t]{2}{*}{ Knee } & Flexion & $\mathrm{F} / \mathrm{F}$ & $1 / 1$ \\
\hline & Extension & $\mathrm{F} / \mathrm{F}$ & $1 / 1$ \\
\hline \multirow[t]{4}{*}{ Ankle } & Dorsoflexion & $\mathrm{F} / \mathrm{F}$ & $1 / 1$ \\
\hline & Plantarflexion & $\mathrm{F} / \mathrm{F}$ & $1 / 1$ \\
\hline & Inversion & $F / F$ & $1 / 1$ \\
\hline & Eversion & $\mathrm{F} / \mathrm{F}$ & $1 / 1$ \\
\hline \multirow[t]{2}{*}{ Big Toe } & Flexion & $\mathrm{F} / \mathrm{F}$ & $1 / 1$ \\
\hline & Extension & $\mathrm{F} / \mathrm{F}$ & $1 / 1$ \\
\hline \multirow[t]{2}{*}{ Toes } & Flexion & $\mathrm{F} / \mathrm{F}$ & $1 / 1$ \\
\hline & Extension & $\mathrm{F} / \mathrm{F}$ & $1 / 1$ \\
\hline
\end{tabular}

Table 2. Neurological and Functional examination Status 


\begin{tabular}{|c|c|c|}
\hline No & $\begin{array}{r}\text { Examination } \\
\end{array}$ & Result \\
\hline \multicolumn{3}{|c|}{ A. Neurological Status } \\
\hline 1 & Cranial Nerve & Normal Limit \\
\hline \multirow[t]{3}{*}{2} & Physicological Reflexes & \\
\hline & BPR | KPR & $+1 /+2 \mid+1 /+1$ \\
\hline & TPR | APR & $+1 /+2 \mid+1 /+1$ \\
\hline \multirow[t]{5}{*}{3} & Pathological Reflexes & \\
\hline & Babinski & $-1-$ \\
\hline & Chaddock & $-1-$ \\
\hline & Hoffman & $-1-$ \\
\hline & Tromner & $-1-$ \\
\hline 4 & Sensory Deficit & Difficult to evaluate \\
\hline 5 & Spasticity & $-\mid-$ \\
\hline 6 & Tonus & Decrease \\
\hline \multicolumn{3}{|c|}{ B. Functional Examination } \\
\hline \multirow[t]{7}{*}{1} & Balance & \\
\hline & Sitting & \\
\hline & Static & Unable \\
\hline & Dynamic & Unable \\
\hline & Standing & \\
\hline & Static & Unable \\
\hline & Dynamic & Unable \\
\hline \multirow[t]{3}{*}{2} & Pulmonary Function & \\
\hline & Count Test & 9 \\
\hline & Chest Expansion & T2-T4-T6: $2 \mathrm{~cm}-2 \mathrm{~cm}-2,5 \mathrm{~cm}$ \\
\hline \multirow[t]{7}{*}{3} & Hand Function & \\
\hline & Grasp & $\mathrm{NF} / \mathrm{NF}$ \\
\hline & Spherical & $\mathrm{NF} / \mathrm{NF}$ \\
\hline & Cylindrical & $\mathrm{NF} / \mathrm{NF}$ \\
\hline & Lateral tip & $\mathrm{NF} / \mathrm{NF}$ \\
\hline & Pinch & $\mathrm{NF} / \mathrm{NF}$ \\
\hline & Hook & $\mathrm{NF} / \mathrm{NF}$ \\
\hline
\end{tabular}

Chest X Ray on April $3^{\text {rd }}, 2019$ shows normal cardiac and suspect pneumoniae (Figure 1), EMG on April 16 ${ }^{\text {th }}, 2019$ shows clinical neurophysiological showed demyelinating motor polyradiculoneuropathy.

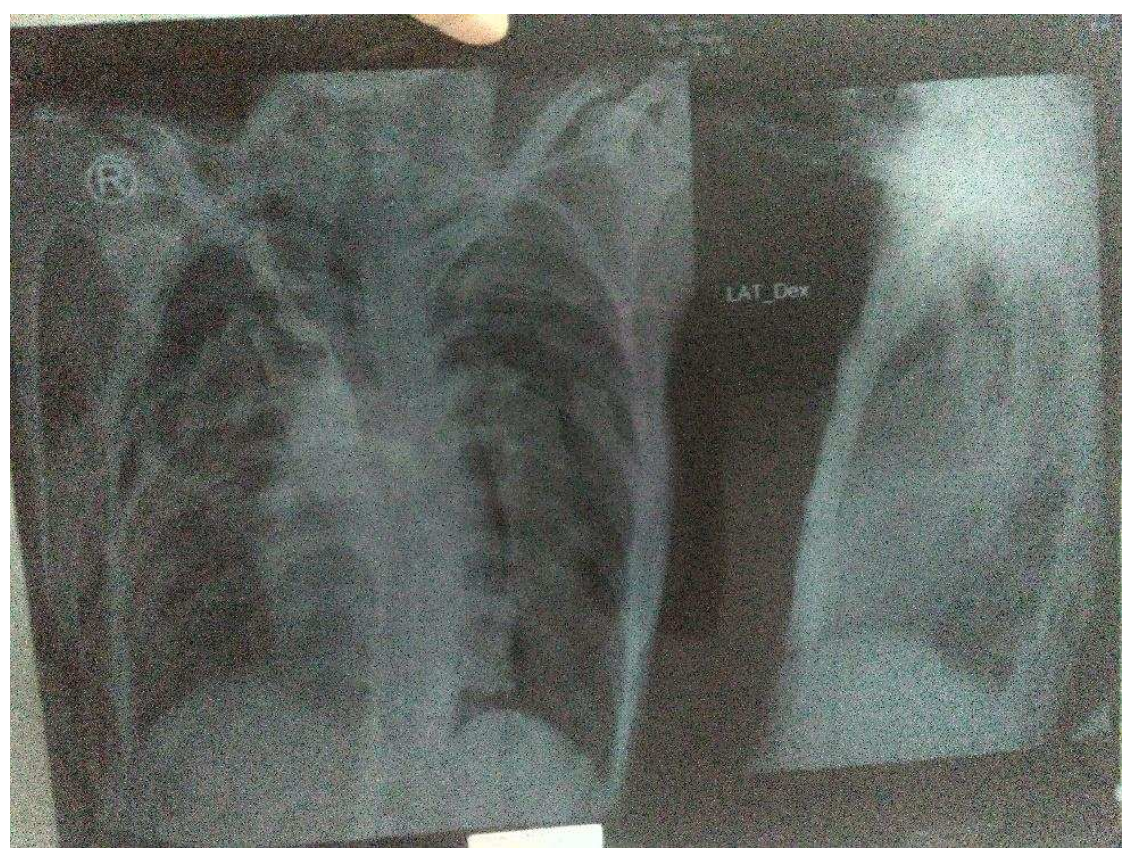

Figure 1. Chest X-ray AP position ( April 3rd , 2019), suspect pneumoniae, normal cardiac.

Based on physical and diagnostic examination patient diagnosed with Tetraparesis LMN type due to Guillan Barre Syndrome (GBS). Functional diagnosis are 1) Impairment: Tetraparesis; 2) Disability: Barthel index was 25 (severely dependent: bathing, dressing, grooming, toilet use, transfer, mobility, stairs); 3) Handicap: patient could not go to school and could not handle normal daily activity. 
Table 3. ICF Classification

\begin{tabular}{|c|c|c|}
\hline \multirow{3}{*}{\multicolumn{2}{|c|}{\begin{tabular}{ll} 
& \multicolumn{1}{c}{ No } \\
A. & Body Function \\
& $1 . \quad$ b1522
\end{tabular}}} & \multirow{2}{*}{ Classification } \\
\hline & & \\
\hline & & His mother worried that her son's condition will last forever \\
\hline & 2. $\mathrm{b} 4350$ & Immune response \\
\hline & 3. b730 & Muscle power function \\
\hline & 4. b7500 & Stretch motor reflex \\
\hline & 5. b7603 & Supportive functions of arm or leg \\
\hline \multicolumn{3}{|c|}{ B. Body Structure } \\
\hline & s198 & Structure of the nervous system, other specified \\
\hline & s730 & Structure of upper extremity \\
\hline & s750 & Structure of lower extremity \\
\hline \multirow[t]{9}{*}{ C. } & \multicolumn{2}{|c|}{ Activity and Participation Limitating } \\
\hline & 1. $\mathrm{d} 230$ & Carrying out daily routine \\
\hline & d420 & Transferring oneself \\
\hline & d430-d449 & Carrying, moving and handling objects \\
\hline & $\mathrm{d} 450-\mathrm{d} 469$ & Walking and moving \\
\hline & $\mathrm{d} 530$ & Toileting \\
\hline & d5 540 & Dressing \\
\hline & 7. $\mathrm{d} 820$ & School education \\
\hline & 8. $\mathrm{d} 920$ & Recreation and leisure \\
\hline D. & \multicolumn{2}{|c|}{ Environtmental Factors } \\
\hline & 1. $\mathrm{E} 580$ & Health services and system \\
\hline
\end{tabular}

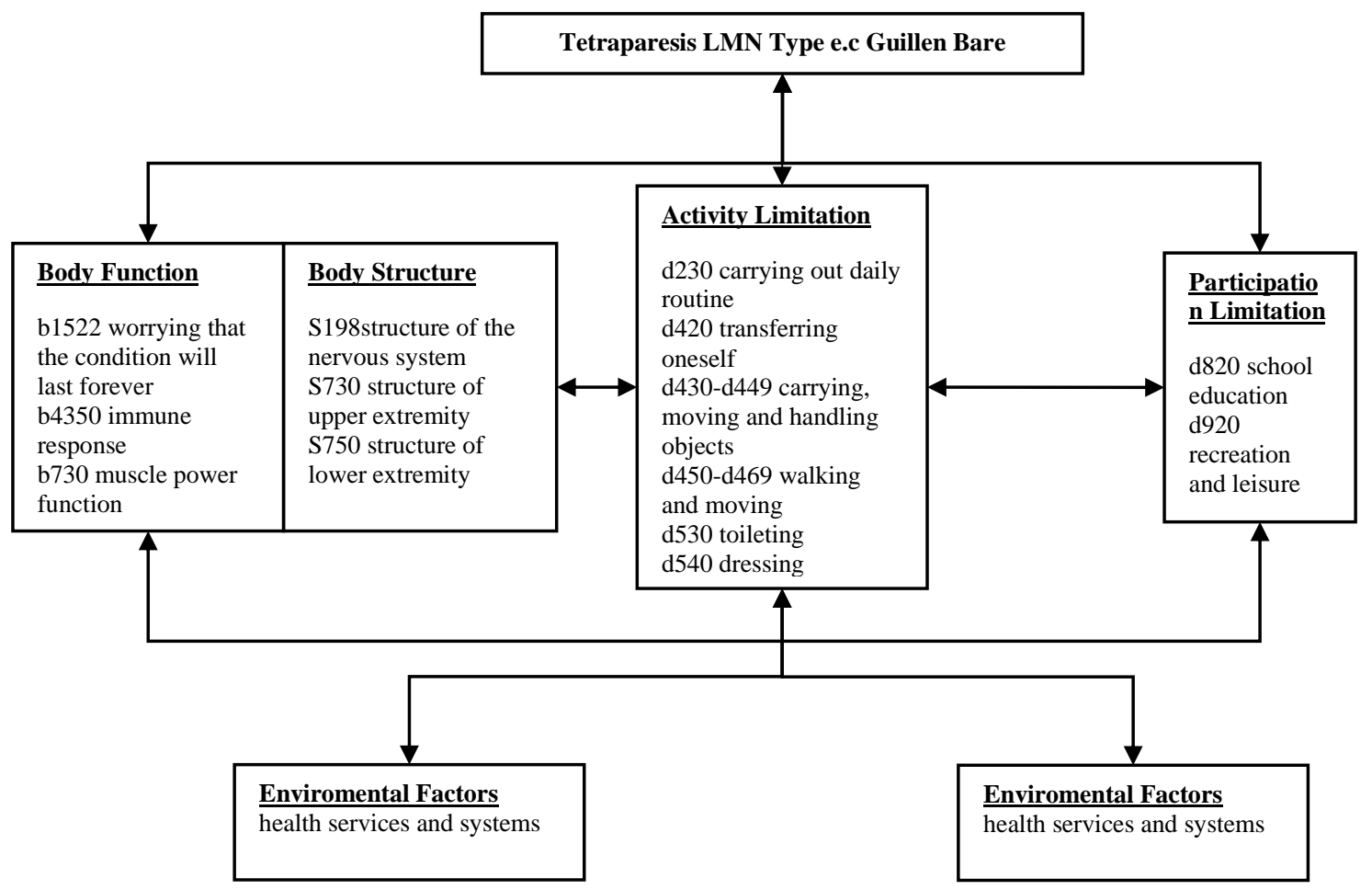

Figure 2. ICF Guillain-Barre Syndrome

Patient medical problem are Tetraparesis LMN Type ec GBS, rehabilitation medicine are R1: dependent ambulation with wheelchair; R2: severely dependent (Barthel Index 25); R7: weakness of upper and lower extremities bilaterally and transfers lying to sitting disturbance. There is no problem in R3 until R6.

Goal of treatment are: 1) short term: Sitting independently and increase the muscle strength; 2) long term: independently ambulation and improvement of quality of life.

Rehabilitation medicines on the table 4 


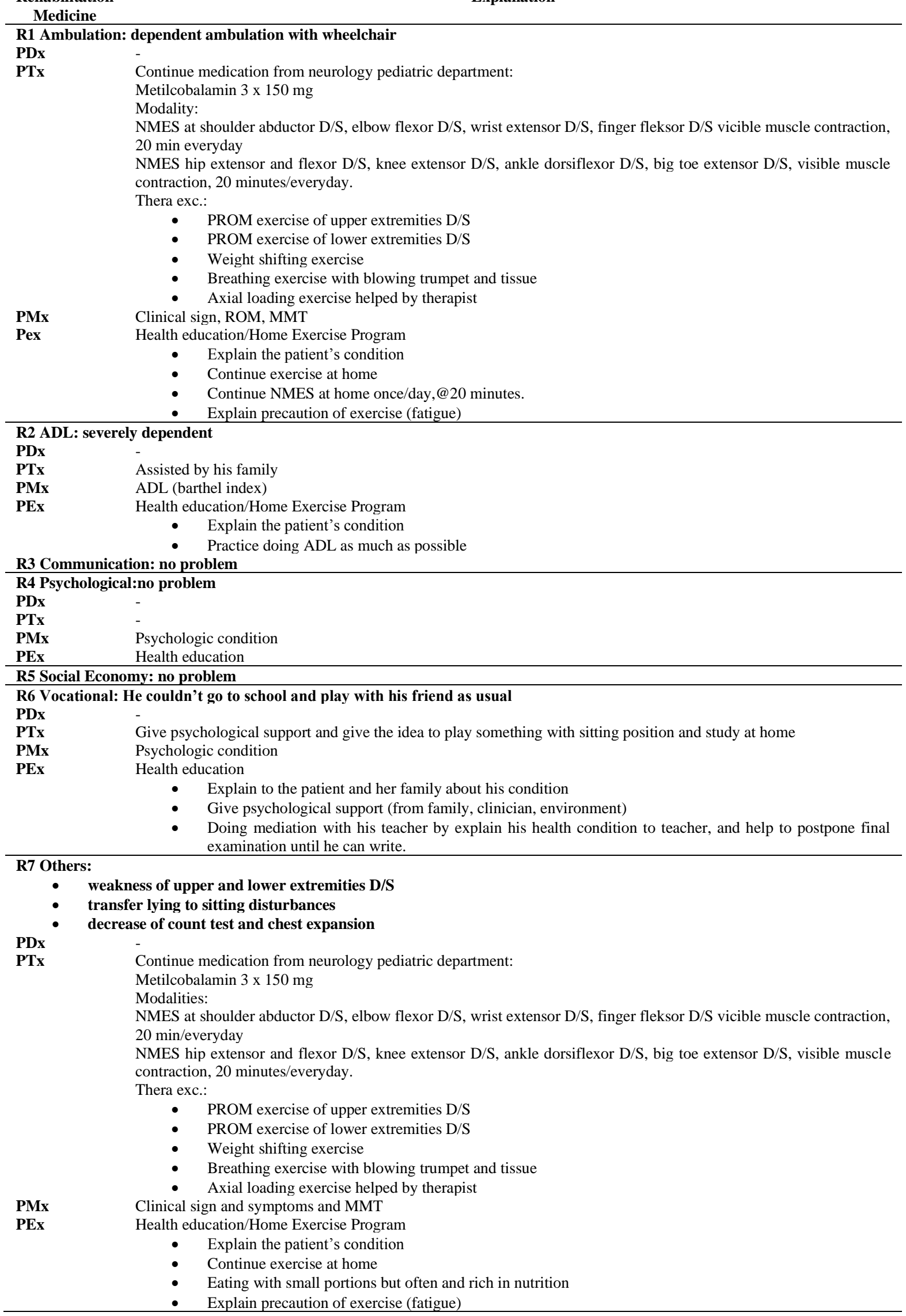

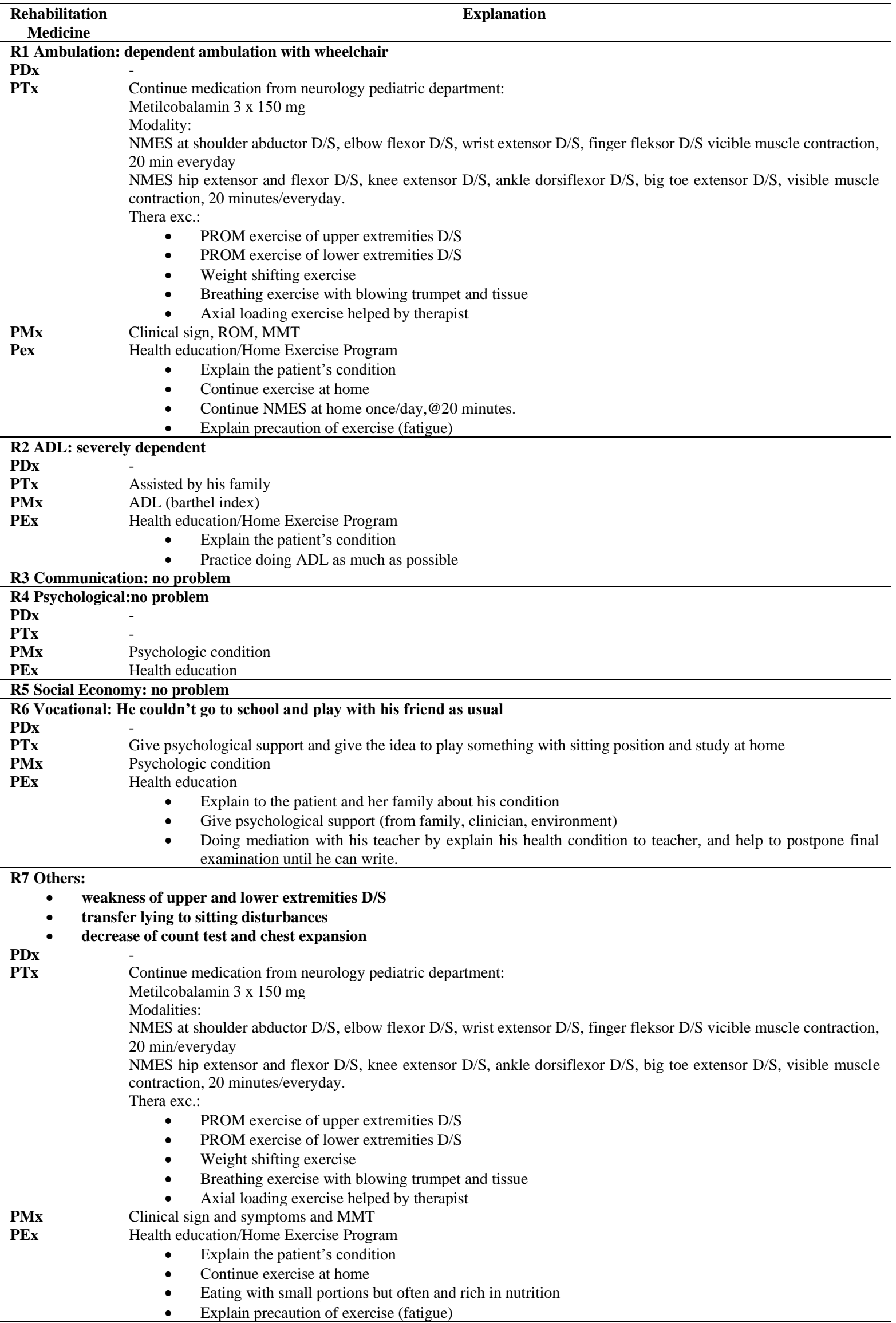


Table 5. Progress note of treatment

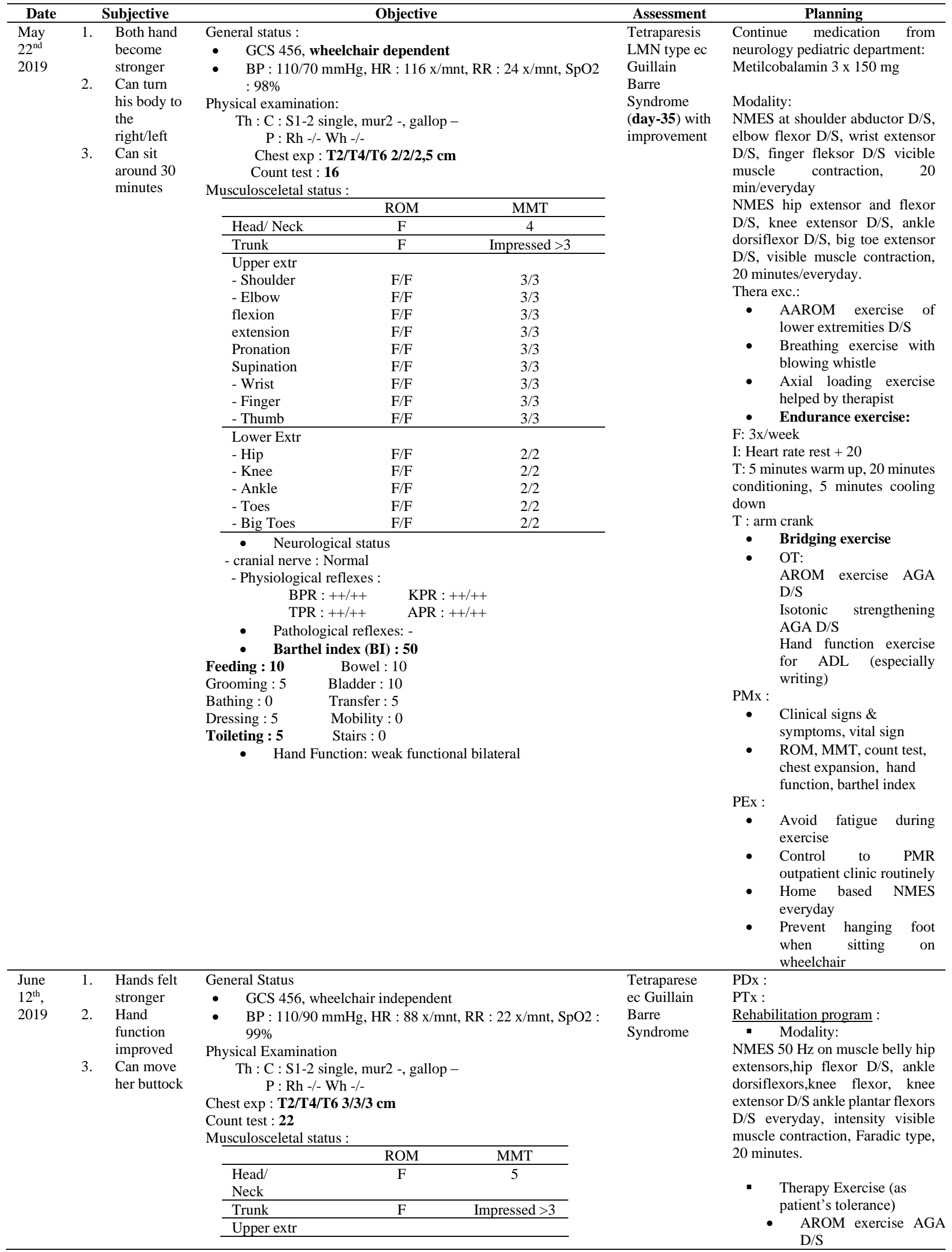




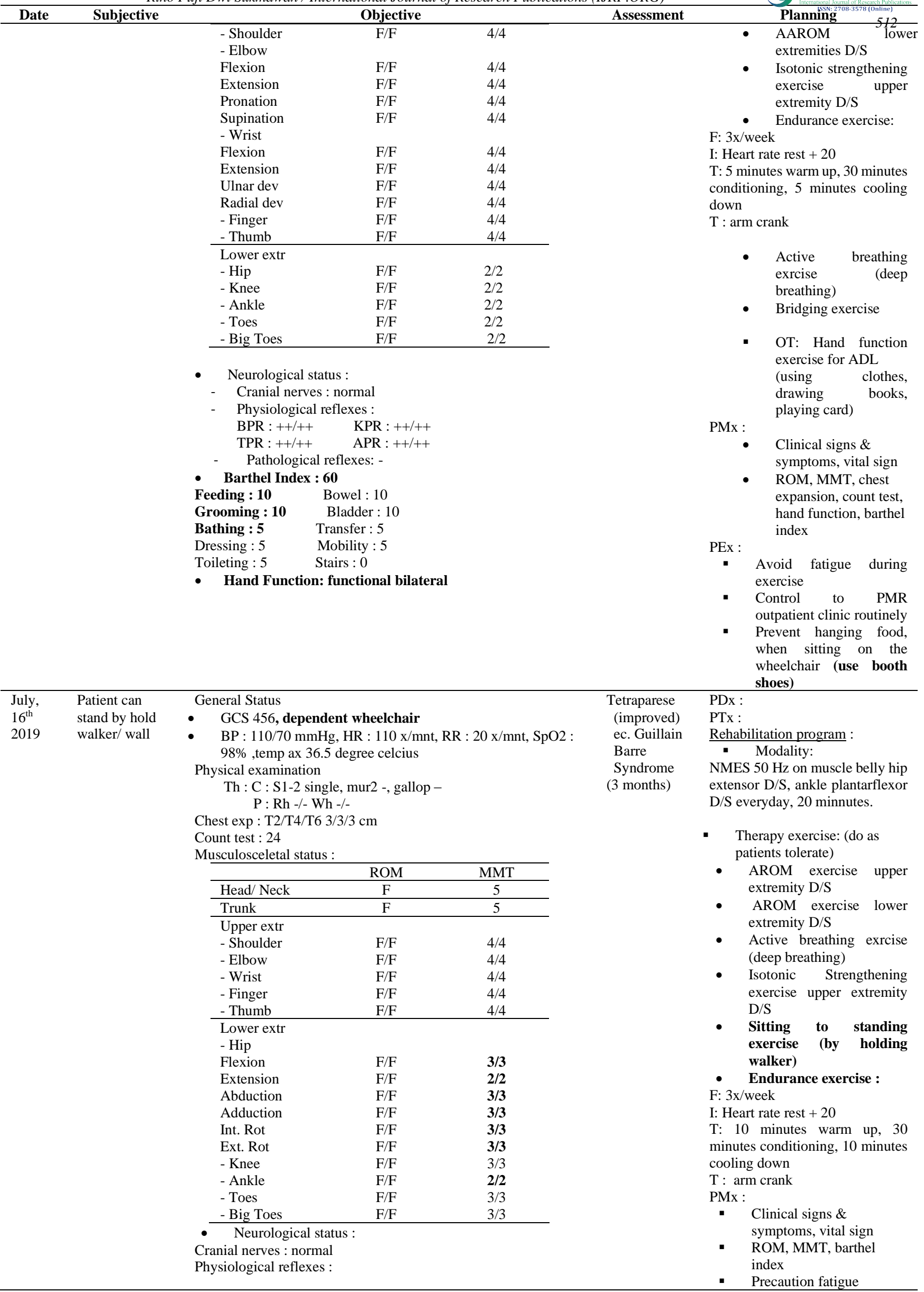




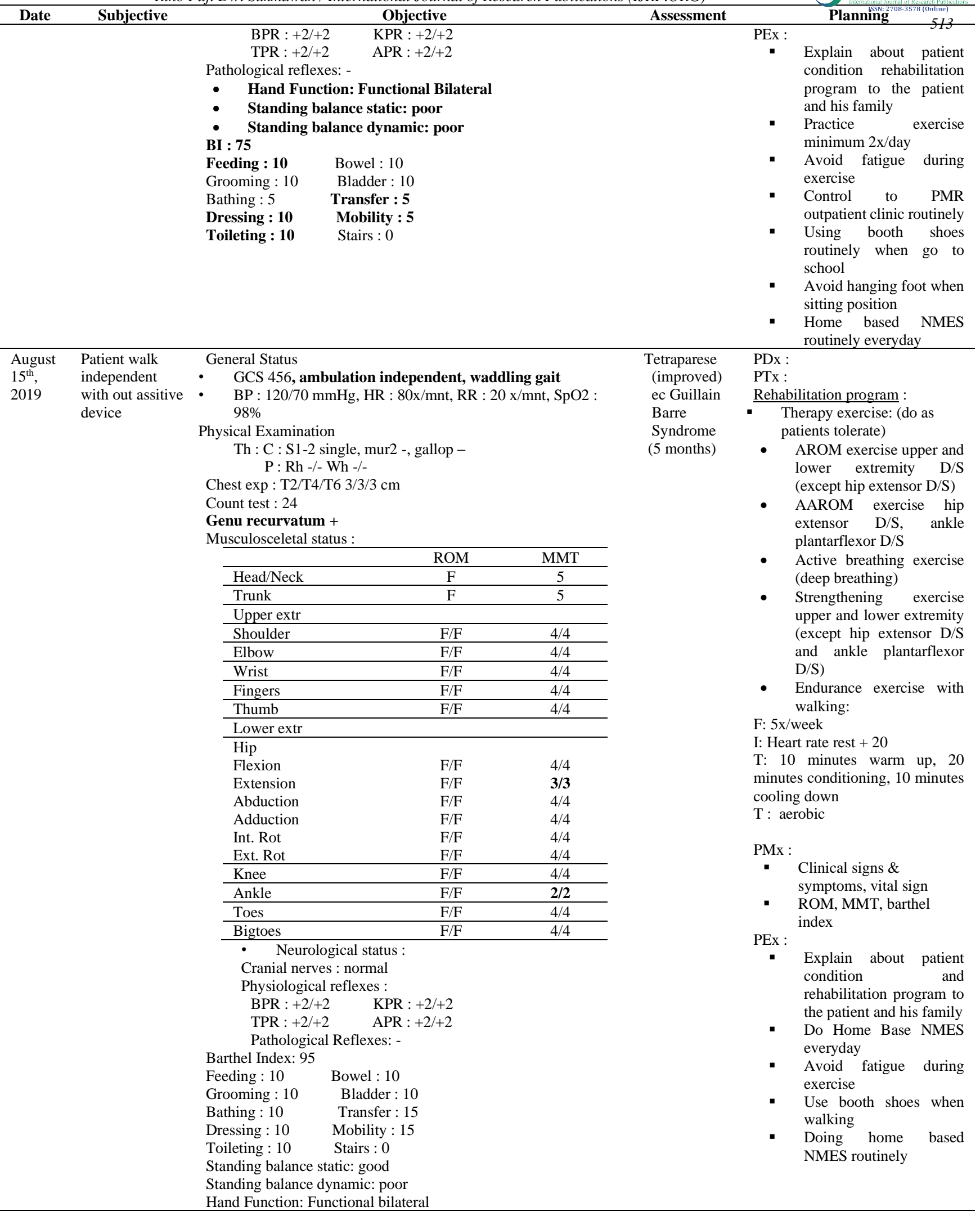




\section{Discussion}

This case explained that 7 years old male children. was presented with main complaint of weakness at extrimites on both side since March 27th, 2019. Diagnosed Tetraparesis LMN type due to GBS. Patient diagnosed by general, physical, and diagnostic examination. Examination shows that patient suffered weakness at lower extrimites gradually followed by upper extrimities, felt numbness on all of extrimity, patient are unable sit and stand, losing all of hand function, difficult to breath suspected of pneumonia, patient experience a stomach discomfort. Barthel index is 25 (severely dependent).

$2^{\text {nd }}$ month rehabilitation, patient shows improvement of upper extrimity muscle tone, grasp, turn his body to the right and left, patient also can sit around 30 minutes. BI increased to 50. $3^{\text {rd }}$ month rehabilitation, patient shows improvement of upper extrimity muscle tone, grasp, move his buttocks. BI increased to $60.4^{\text {th }}$ month rehabilitation, patient shows improvement of lower extrimity muscle tone, patient can stand by hold walker/wall. BI increased to $75.5^{\text {th }}$ month rehabilitation, patient can walk independent without assistive device. BI increased to 95.

GBS more favorable in children than in adults (Andary, 2021). The average incidence was 0.82 cases per 100,000 children aged $<15$ years (Landaverde et al., 2010). This patient experiencing decreased tendon reflexes in the affected extremity All children had weakness of bilateral limbs and disappearance or reduction of tendon reflex, and limb weakness reached the highest level of severity within 4 weeks (Ju-Fang et al., 2021) and pneumonia (Katirji, 2016). Some patients have symptoms of cranial nerve disorders, most commonly facial, oculomotor or bulbar weakness and ataxia known as Miller Fisher Syndrome (Thomas and Therattil, 2010). Patient got rehabilitation medicines consist of NMES, ROM. Occupational therapy professionals should be involved early in the rehabilitation program to promote positioning, posture, upper body strengthening (Craig, Richardson and Ayyangar, 2016), range of motion (ROM), and activities that aid functional self care (Andary, 2021).

Patient also undergo active breathing, endurance, strengthening, transfer and mobilization exercise, occupational therapy. Patient got improvement in muscle power of upper and lower extremities after five (5) month rehabilitation medicines. The recovery period often weeks to months, with a median estimated recovery time of 6-12 months. Full recovery within 3-12 months is experienced by $90-95 \%$ of pediatric patients with GBS (Andary, 2021). Barthel index also improved to 95. Patient can do activity daily living independently

Family counseling and education is extremely important early in the illness. The family must be prepared for a prolonged and potentially complicated course of illness.

\section{Conclusion}

This report established that male children suffering tetraparese due to GBS was able to increase physical strength and Activity Daily living following a five (5) months rehabilitation medicine using the NMES, ROM, active breathing, endurance, strengthening, transfer and mobilization exercise, and occupational therapy.

\section{References}

Andary, M. T. (2021) Pediatric Guillain-Barre Syndrome: Background, Pathophysiology, Etiology. Available at: https://emedicine.medscape.com/article/1180594-overview\#showall (Accessed: 8 January 2022).

Craig, A., Richardson, J. K. and Ayyangar, R. (2016) Rehabilitation of Patients with Neuropathies in Braddom's Physical Medicine \& Rehabilitation. 5th edn. Edited by D. Ccifu. Philadelphia: Elsevier.

Ju-Fang, L. et al. (2021) 'Clinical features of children with Guillain-Barré syndrome and the significance of Brighton criteria’, Chin J Contemp Pediatr, 23(2). doi: 10.7499.

Katirji, B. (2016) Disorders of Peripheral Nerves in Bradley's Neurology in Clinical Practice. 7th edn. Edited by Andy. Philadelphia: Elsevier.

Landaverde, J. et al. (2010) 'Guillain-Barré syndrome in children aged < 15 years in Latin America and the Caribbean: baseline rates in the context of the influenza A (H1N1) pandemic', J Infect Dis, 201(5), p. 746.

Thomas and Therattil (2010) Peripheral neuropathy in Delisa's Physical Medicine \& Rehabilitation, Principles and Practice. 5th edn. Philadelphia: Lippincott Williams \& Wilkins. 